\title{
Theocentrism in Edith Stein's (St. Teresa Benedicta of the Cross's) Late Anthropology
}

\begin{abstract}
This article proposes the thesis that Edith Stein's late anthropology has a theocentric orientation. The threefold structure of a human being consisting of a body, soul and spirit is examined in order to validate the thesis. First of all, the finitude of a human being points out to the eternal being and - consequently - human beings are not conceivable by themselves, without the context of God. Moreover, the hylomorphic union of the body and soul adopted from Aristotelian and Thomistic philosophy is enriched in Stein's anthropology by the concept of spirit. This results in a threefold structure and is reason enough to suggest man's iconic similarity to the Trinity. Furthermore, Stein takes over St. Teresa of Avila's concept of an internal center of the soul, which can be a meeting point between a person and God. The analysis of the soul's center supports the main thesis ${ }^{1}$.
\end{abstract}

\section{Keywords}

Saint Teresa Benedicta of the Cross (Edith Stein), theocentrism, threefold structure of the human being, body, soul, spirit.

Edith Stein's life consisted of one exceptional event after another. Her childhood decision to abandon Jewish faith and admit to atheism, stopping her education at a young age when she did not feel it was right to continue,

1 In this article in order to refer to a human being I will use the terms 'human being' and 'man' interchangeably. In doing so I follow the English translations of Stein's writing as well as some English commentaries on her work. A number of English authors use the term 'human person' in reference to Stein's anthropology, which I shall not do. In rare instances, when referring to passages in which Stein used the German word 'die Person' instead of 'der Mensch', I will use the English word 'person'. 
her critical and strong headed approach to psychology that made her search for a well-founded discipline of thought, the passionate phenomenological research she did by the side of Edmund Husserl, her dramatic decision to receive baptism in Catholic Church despite strong family tradition, her uncompromising rejection of all atheistic thinking after conversion and joining the Discalced Carmelite Order at the mature age of forty two having known that it meant her mother's final rejection - needless to say, these all are signs of a strong, independent and non-conformist character. It is, therefore, no wonder that the history of Edith Stein's life intrigues to such an extent that it almost overshadows one of the most important aspects of her life - her thinking.

A careful reading of Edith Stein's autobiographical work ${ }^{2}$ leads to the conclusion that it was philosophy that played the most notable role in her life. And it was the human being that played the central part in her philosophy. Throughout her whole life Stein kept asking the same anthropological question: what is a human being? In the early stages of her philosophical reflection she searched for the answer using Edmund Husserl's phenomenological methodology. After converting to Catholicism her anthropology needed a new theoretical foundation. A temporary decision to abandon all philosophical, hence non-dogmatic - as she all too quickly assumed - research was followed by the acceptance of the foundation she discovered in the works of early Christian philosophers such as Pseudo-Dionysius the Areopagite, the Church Fathers, particularly St. Augustine of Hippo and medieval scholastic thinkers, especially St. Thomas Aquinas. As already stated, the anthropological question remained Stein's focal point in most of her work ${ }^{3}$. The answer to

2 The collection of letters: Selbstbildnis in Briefen I (1916-1933), Freiburg 2010, Herder; Selbstbildnis in Briefen II (1933-1942), Freiburg 2006, Herder, both volumes are translated in English in one volume: Self-Portrait In Letters, 1916-1942, trans. J. Koeppel, OCD, Washington 1993, ICS Publications; Selbstbildnis in Briefen III: Briefe an Roman Ingarden, Freiburg 2005, Herder, as well as the history of Stein's family written already after she joined Carmelite: Aus dem Leben einer jüdischen Familie und weitere autobiographische Beiträge, Freiburg 2010, Herder, English translation: Life in a Jewish family, trans. J. Koeppel OCD, Washington 1986, ICS Publications.

3 The doctoral dissertation Zum Problem der Einfühlung, Freiburg 2010, Herder, English translation: On the problem of empathy, trans. W. Stein, Washington 1989, ICS Publications; the winter semester lectures at The German Pedagogical Institute: Was is der Mensch? Theologische Anthropologie, Freiburg 2005, Herder; the spring semester lectures: Der Aufbau der menschlichen Person. Vorlesung zum Philosophischen Anthropologie, Freiburg-Basel-Wien 1994, Herder, Freiburg 2010; Die Frau, Freiburg 2010, Herder, translated in English by F. M. Oben, Essays 
the question about the human being, however, changed over time. Her early reflection was a contribution to Husserl's phenomenological school and shows little signs of interest in man as God's creation. Her later reflection, on the contrary, perceives the human person as nonsensical without the context of his maker.

The aim of this article is to discuss this dependence, of a human being on God, in Stein's later anthropology ${ }^{4}$. The term proposed in this article in order to describe God's role in Stein's post-conversion anthropology is 'theocentrism'. This article will first discuss this term and its origin and will proceed to the representation of crucial elements of Stein's late anthropology that show the central role of God in a human being's structure and existence. The main thesis proposed in this article states that in Stein's late anthropology a man is not conceivable when deprived from the context of God.

\section{Theocentricity}

The term 'theocentrism' and its antonym - egocentrism - appear in Stein's non-academic text written in order to honor Edmund Husserl's seventieth birthday. The paper entitled What is philosophy? A conversation between Edmund Husserl and Thomas Aquinas was published in 1929 in the Phenomenological Yearly Book edited by Husserl ${ }^{5}$. It comprises the dialogue

on Woman, Washington, 1996, ICS Publications; Welt und Person, Louvain 1962, Editions Nauwelaerts; Endliches und ewiges Sein, Freiburg in Breisgau 1984, Herder, the new edition: Endliches und ewiges Sein, Freiburg 2013, Herder; English translation: Finite and eternal being, trans. K. F. Reinhardt, Washington 2002, ICS Publications; Geistliche Texte I, Freiburg 2014, Herder; Geistliche Texte II, Freiburg 2007, Herder.

4 I focus on the post-conversion papers, for the detailed list see all works enlisted in footnote 2, except for Stein's Ph.D. thesis - Zum Problem der Einfühlung - written before the conversion. I do not discuss Stein's latest publication Kreuzeswissenschaft, which was devoted to the interpretation of Saint John of the Cross's writings. It is, however, the case that Stein's latest work circles around anthropological questions as much as the earlier one.

5 The text published in the Yearly Book was shortened according to editor's (whom at a time was Martin Heidegger) demand and given a title: Husserls Phänomenologie und die Philosophie des hl. Thomas von Aquino: Versuch einer Gegenüberstellung, in: Jahrbuch für Philosophie und phänomenologische Forschung, Festschrift fur Edmund Husserl, zum 70. Geburstag gewidmet, Halle 1929 p. 315-338. It also did not have a dialogical form but that of an academic paper. Translated in English by M. C. Baseheart, Husserl's Phenomenology and the Philosophy of St. Thomas Aquinas. Attempt at comparison, in: Person in the World: Introduction to the Philosophy of Edith Stein, Dordrecht 1997, Kluwer, p. 129-144 and 179-180. The full version of this text in 
between St. Thomas Aquinas and Edmund Husserl, in which the prolocutors discuss the proper object of philosophy and a number of methodological issues. Not least among them is the topic of basic axioms of philosophy. The imaginary St. Thomas rightly argues that Husserl's phenomenological method leads him to accept a subject - an ego - as the starting point and center of philosophy ${ }^{6}$. Thomas himself took on a different course: accepted God as truth, a first principle and a criterion for truth of every part of creation. Establishing God as an axiom results in St. Thomas's philosophy having a theocentric orientation, whereas establishing the ego as an axiom makes Husserl's phenomenology have an egocentric one: 'From the different goals that are posited and the different conceptions of the ground of certitude there had to result a completely different orienting of the total philosophy'?

The original use of the term 'theocentrism' differs in one aspect from the one proposed in this article. Stein's theocentricity applies to her philosophical system as a whole, whereas in this article the term theocentricity applies to her anthropology. The term used in this article is therefore narrower in its scope. Apart from that limitation, the semantics of the term remains as it originally appeared in Stein's work: Stein's anthropology is theocentric in the sense that it conceives a human being to have his first principle in God, who conditions the creation of a man and remains a necessary, shaping element of his existence.

During a series of lectures on anthropology, which Stein gave at The German Pedagogical Institute in the winter and spring semesters of 1932 and 1933, she admitted the above described orientation of her anthropology ${ }^{8}$. The being, that is the subject of her research, has the essential property of finitude - she argued in the ninth lecture. As such, it cannot be completely understood by itself, since it always points out to the first being which is

its original, dialogical form was published in the $15^{\text {th }}$ volume of Edith Steins Werke: Erkenntnis und Glaube, Freiburg 1993, Herder, entitled Was Ist Philosophie? Ein Gespräch zwischen Edmund Husserl und Thomas von Aquino.

6 E. Stein, Husserl's Phenomenology and the Philosophy of St. Thomas Aquinas. Attempt at comparison, in: M. C. Baseheart, Person in the World: Introduction to the Philosophy of Edith Stein, Dordrecht 1997, Kluwer, p. 135.

7 Ibid.

8 E. Stein, Was is der Mensch? Theologische Anthropologie, Freiburg 2005, Herder; E. Stein, Der Aufbau der menschlichen Person. Vorlesung zum Philosophischen Anthropologie, Freiburg 2010, Herder. 
eternal or - to be more precise - which is eternity itself. ${ }^{9}$ Such a being, Stein called God, since it has properties corresponding to the idea of God. According to her ontological conviction, a human being - as well as everything that is finite - points to God and would not be graspable without the relation to God: in both that it is (exists) and in what it is. God is the theoretical framework in which a human being makes sense.

This brief recapitulation of the orientation of Stein's late anthropology leaves us with little doubt: Stein was clearly convinced that a human is not comprehensible without the eternal being of God. At the very beginning of her anthropological research she accepted what, in respect to Aquinas's philosophy, she called a theocentric orientation. The justification for her doing so lies in man's finitude.

\section{Finitude}

Stein's treatment of the term 'finitude' is not merely an assertion of the fact that a man has his beginning in a Godly act of creation. This by itself is a classical religious understanding of man's appearance in the world as a consequence of divine creation. The manifold meanings of the term 'finitude' include the fact that whatever is finite is also temporal, as a result of having a beginning. Temporality, in turn, indicates a dynamic character. Stein concluded that finitude signifies a being that does not possess its own existence, and in order to achieve existence, it needs time. Time is necessary, for a being that has a beginning, in order to become what it is - she wrote $^{10}$. Moreover, man as a finite being, always has but a temporal existence, and has no control over his beginning, nor complete control over his end. In other words, the finite being is not a master of existence - there is only one such master and it is, needless to say, an eternal being who knows no limits ${ }^{11}$. Therefore, the finitude of a man, mankind's basic characteristic, always calls for a limitless being. The above represented initial conceptualization of a man as finite remains in accordance with the proclaimed theocentric orientation

9 E. Stein, Der Aufbau der menschlichen Person. Vorlesung zum Philosophischen Anthropologie, Freiburg 2010, Herder, lecture IX.

${ }^{10}$ E. Stein, Endliches und ewiges Sein, Freiburg in Breisgau 1984, Herder, p. 60.

${ }^{11}$ Ibid. 
of Stein's anthropology. The question we now ought to ask is: 'What are the other essential features of man?'.

\section{The body-soul-spirit structure}

First of all, a human being has a body-soul-spirit structure. ${ }^{12}$ This statement takes us back to the First Letter to Thessalonians in which St. Paul uses the soul-body-spirit distinction ${ }^{13}$, without any elaboration on it, however. Stein's recapitulation of it is coherent with dogmatic thought, yet it is a step away from St. Thomas's views. Aquinas inherited an Aristotelian vision of man as a hylomorphic unity of body and soul. In her basic conceptualization of the structure of man, Stein reaches to St. Paul's triadic view presenting a man as a union of three elements: body, soul and spirit; a view present in the work of Origen. Thereby, she departs from Aquinas's dual understanding of man, not abandoning the scholastic vision of a man as a composition (gr. synolon) of a form and matter, however. The choice of reaching to St. Paul's structure is justified by the iconic character of man. Stein's reasoning is very much in line with St. Augustine's argumentation from De Trinitate ${ }^{14}$ : since man has been created in the image of God, and God is the Trinity, therefore signs of this Trinity ought to be present in man. Stein follows in St. Augustine's footsteps when she sets out to discover the traces of the Trinity in creation. She is original, nevertheless, in finding God's image in the basic structure of body, soul and spirit. The identification of the threefold structure with the iconic character of man remains in line with theocentric orientation.

Body, soul and spirit create an inseparable unity, they each have, however, a distinct meaning. A few comments about each are in order.

\subsection{The body}

Stein's understanding of a human body in her late anthropology has much in common with what she wrote about in her early phenomenological period. In her doctoral dissertation, On the problem of empathy, she differentiated

\footnotetext{
12 Ibid., p. 336.

131 Thessalonians, 5: 23.

${ }^{14}$ St. Augustine, On the Trinity, trans. A. W. Haddan, Books IX-XV, online source: - http://www.logoslibrary.org/augustine/trinity/index.html (20.05.2014).
} 
between a living body - Leib - and a physical body - Körper ${ }^{15}$. A living body has a unique property of the possibility of being perceived from within, and a physical body can only be perceived from the outside: that is what makes the crucial difference between the same body when it is alive or dead. In her later anthropology Stein still held this basic distinction together with a number of phenomenological findings on the givenness of the living body. In the work entitled Natur, Freiheit und Gnade, that was known under an incorrect title Die ontische Struktur der Person und ihre erkenntnistheoretische Problematik and was written just after Stein's conversion, she repeated that distinction ${ }^{16}$. Were she to stop her theorization at this point there would be no real reason to detect theocentrism in her concept of a body. Yet Stein enriched her phenomenological research with a number of thoughts inspired by scholastic philosophy and Christian mystical works.

First of all, she accepted a hylomorphic understanding of the body-soul relation: the living body consists of matter shaped by the soul which has a capacity to form something ${ }^{17}$. Secondly, she established a hierarchy between the shaping and the shaped: a body is to be subordinated to a soul and serve as an instrument of a person's activity ${ }^{18}$. This does not result in Stein accepting an anti-somatic standpoint: the living body is a mirror that reflects the life of a soul and has, therefore, a dignity of what it reflects. The structure of body and soul is directed towards the inner life (Innenleben ${ }^{19}$ ) and a body performs its functions best when it causes no disturbances to that inner life ${ }^{20}$. The bodysoul relation might take on a different character, however, especially in the case of uncontrolled bodily instincts keeping the person away from entering

${ }^{15}$ E. Stein, On the problem of empathy, trans. Waltraut Stein, Washington 1989, ICS Publications, p. 41.

${ }^{16}$ E. Stein, Welt und Person, Louvain 1962, Editions Nauwelaerts, p. 172. She writes: 'Der Leib ist als solcher charakterisiert und von dem puren materiellen Körper, der ihn mitkonstituiert, dadurch abgehoben, daß alle seine Zustände und alles, was ihm widerfährt, gespürt wird oder doch gespürt werden kann. Alles Leibliche hat eine Innenseite, wo Leib ist, da ist auch ein inneres Leben'.

${ }^{17}$ E. Stein, Endliches und ewiges Sein, Freiburg in Breisgau 1984, Herder, p. 229.

${ }^{18}$ E. Stein, Welt und Person, Louvain 1962, Editions Nauwelaerts, p. 175-176.

${ }^{19}$ Ibid., p. 175.

${ }^{20}$ This does not mean that people are naturally self-reflective, rather than engaged in the world. In the later work, Endliches und ewiges Sein, chapter VII, § 9 Das Gottesbild im Menschen, point 4. Das Innere der Seele, Stein elaborates on a person's tendency to reach out to the world and a difficulty to stay inside. The call to go back inside comes from the conscience, a successful preaching or as a result of an important life happening. 
the internal life. Stein was aware of such possibilities and remained convinced that true richness lies inside the human ready to be discovered. The body is just an external, material manifestation of a person and a tool for the soul to live its life. The richness that lies within is non-material, it is spiritual. Stein called it with a term derived from St. Teresa of Avila's most important work, Castillo interior o las Moradas: an internal castle (Die Seelenburg ${ }^{21}$ ).

\subsection{The soul}

Stein understood the soul not just as a non-material, formal element of the body-soul-spirit triad, an Aristotelian morphe in Greek terms. Following in the footsteps of the Spanish mystic she understood the soul also as an internal structure of layers of depth alike St. Teresa of Avila's castle. She did not go too far in following St. Teresa's thought: it was not her interest to describe the kinds of peripheral and internal chambers of that castle ${ }^{22}-$ she did however accept the idea of the most cardinal chamber. The conceptualization of that chamber is particularly interesting for our investigation of Stein's theocentricity.

\subsection{Center of the soul}

The most internal part of a person is called either the center or the depth. It is located so deep that one cannot easily come in touch with it. This very center of the soul is the source of human activity, freedom and inspiration. Stein wrote about it: 'Das Getriebe des natürlichen Seelenlebens rührt nicht an das Zentrum, das der Ort der Freiheit und die Ursprungsstelle der Aktivität ist. Die geleitete Seele horcht mit eben diesem Zentrum nach oben, empfängt hier die Weisungen von oben und läßt sich von hier aus gehorsam durch sie bewegen. Die Aktivität ist an ihrer Ursprungsstelle unterbunden, von der Freiheit wird am Ort der Freiheit kein Gebrauch gemacht ${ }^{23}$. The above stated directedness of the center of the soul towards something higher discloses an important aspect. The soul's center is a source of some of a person's movements or inspirations: those originating 'above'. The 'above' is a reference to the

${ }^{21}$ E. Stein, Welt und Person, Louvain 1962, Editions Nauwelaerts, p. 39.

${ }^{22}$ Saint Teresa of Avila identifies seven chambers including the peripheral chambers representing human involvement in the external world, more internal rooms representing selfreflection and a central, seventh chamber inhabited by The Ruler of the Castle - God Himself. She describes the gate to the castle: prayer. For more see Saint Teresa of Jesus, The interior castle or the mansions, trans. Benedictines from Stanbrook, London 1921, Thomas Baker.

${ }^{23}$ E. Stein, Welt und Person, Louvain 1962, Editions Nauwelaerts, p. 138. 
eternal being of God. The center is, therefore, the domain of a person where something other than a human being can enter: it is the most internal part of a man, yet external to him, since it can be filled with somebody's else's ideas.

This understanding of the soul's center filled with God's inspirations or even - in some occasions - inhabited by God is probably the most explicit formulation of the theocentricity of Stein's late anthropology. Here theocentricity means - almost literally - that God's inspirations are present in a human's center ${ }^{24}$. A couple of remarks about that connection of the center with God are necessary here.

Firstly, let us regard the perplexities of Stein's description of that connection. She wrote about a center that is anchored (veranker $\left.{ }^{25}\right)$ above. This means that the center is sturdily, yet temporally connected to God but not necessarily that God is in any way present in the deepest part of a human's soul. Stein also wrote that a soul at its center is directed towards the 'above' and that this center remains passive in receiving movements or inspirations. This also does not imply the actual presence of God in a human's most internal domain. We should be careful to note the difference between the internal part of the soul being connected to the 'above' from which it receives movements and the internal part being filled with God's presence.

Some other fragments of Stein's work might give rise to the idea that God can at times be present in a human's center. Those are, however, exceptional instances. In Endliches und ewiges Sein ${ }^{26}$ Stein described The Ascent of Mount Carmel by St. John of the Cross in short: the difficulties of directing oneself towards the inside, the initial bewilderment of soul's silent center, the disturbing need of activity, the struggle of suppressing this need to act and eventually the experience of an event that keeps a person inside. By this Stein related to what the masters of mystical life called unio mystica: after the humble effort of awaiting at the depth of the inside - a sudden intrusion of a higher, supernatural, godly life. At such a moment of grace a human is given an experience of what faith teaches: the idea that God inhabits a human's soul. In such a context a soul might be called a house for God. In the case of unio

${ }^{24}$ The expression is not used literally, since 'the center' is not understood as a location in space. The soul is a non-material substance, so it cannot have a spatial centre.

${ }^{25}$ E. Stein, Welt und Person, Louvain 1962, Editions Nauwelaerts, p. 138, the same expression is repeated in Endliches und ewiges Sein, Freiburg in Breisgau 1984, Herder, for example p. 408.

${ }^{26}$ E. Stein, Endliches und ewiges Sein, Freiburg in Breisgau 1984, Herder, p. 406-408. 
mystica the center of a human's structure is in fact filled with God's presence. Stein wrote: 'Der Mittelpunkt der Seele ist der Ort, von dem aus die Stimme des Gewissens sich vernehmen läßt, und der Ort der freien persönlichen Enscheidung. Weil es so ist und weil zur liebenden Vereinigung mit Gott die freie persönliche Hingabe gehört, darum muß der Ort der freien Entscheidung zugleich der Ort der freien Vereinigung mit Gott sein' ${ }^{27}$. The precondition of the God-human union is that both united elements are made out of the same substance. God is a spirit and it is a human's spirit - the third element of the structure of a man - that makes the union of the two possible. We have stated that a soul is not material but spiritual. The question arises then - how do the soul and the spirit differ from one another? Before we answer that, a final remark on the soul is needed.

Besides the soul being a center point in the sense that it is the deepest point of a person, a soul is the center in yet another meaning: it is the element of the triadic structure that mediates between the other two: body and spirit, and thereby is centrally located in the whole structure ${ }^{28}$. Being an in-between element does not imply that a soul is a third part of the person, next to body and spirit. In order to explain why, I will return to the above stated question about the difference between soul and spirit and focus on Stein's understanding of a human spirit.

\subsection{The spirit}

The most characteristic feature of a human spirit is its dynamicity ${ }^{29}$. The spirit is that which remains present at all times in a man's soul and at the same time reaches out to the world. In doing so, the spirit loses none of its potency. This activity of a soul has a lot in common with the Neoplatonic idea of the profusion of good: it can also endlessly give itself away, losing none of its potency. The spiritual aspect of a man is responsible for interferences with the world. This is why Stein frequently talks about the domain of spirit or the

27 E. Stein, Welt und Person, Louvain 1962, Editions Nauwelaerts, Die Seelenburg, p. 67.

${ }^{28}$ E. Stein, Endliches und ewiges Sein, Freiburg in Breisgau 1984, Herder, p. 342-343, also E. Stein, Welt und Person, Louvain 1962, Editions Nauwelaerts, Die Seelenburg, p. 39: 'In unserem Zusammenhang ist die rein theoretische Aufgabe zu lösen, im Stufenbau des Seienden die Eigentümlichkeit des menschlichen Seins herauszuarbeiten, und dazu gehört die Kennzeichnung der Seele als der Mitte des ganzen leiblich-seelisch-geistigen Gebildes, das wir Mensch nennen'.

${ }^{29}$ See E. Stein, Endliches und ewiges Sein, Freiburg in Breisgau 1984, Herder, chapter VII, § 2: Person und Geist. 
domain which the spirit penetrates. All human activities and man-made things are marked by a spirit whose stamp remains in them. In order to explain this, a cross-reference to the idea of the soul's center is necessary.

There is an important role which the center of a soul plays, namely, being the carrier of a person's unique character. In Stein's discussion the spirit is present inside a person and at the same time reaches out to the world and human creations, however unusual it might sound. She states that the stamp with which a person's character marks all his activities is located in the depth of a soul. A soul is something by itself - it has its own, unique character, with which the whole of a man's life is marked ${ }^{30}$. What is principium individuationis of each person then: the spirit or the soul?

Stein rejected the Thomistic conception of the principle of individuality situated in matter. St. Thomas accepted matter as a differentiating element of many individuals of the same kind, since he could not place principium individuationis in a form which - by definition - is that which is the same in each example of a certain kind. He settled therefore with accepting the second of the two: matter being a principle of a unique character of each person. Stein, who adopted St. Paul's threefold structure of a man, had enough possibilities left in her basic distinctions to avoid St. Thomas's conclusion. She identified the essence of man with the spiritual soul's center - different in each person. The question raised above - whether it is the soul or the spirit that is the carrier of the essence of each man-overlooks the fact that a soul is made up of spiritual matter. This explains why the soul is not a third part of a person's whole being - the soul is a structure, a form which shapes the union of the two substances: material (body) and spiritual (spirit). Substantialization of the soul leads to a false presumption that a soul is a part of a human being. Just as the form of a chair is not part of a chair - a soul is not part of a human being. Man's position in the hierarchy of beings is in between material and non-spiritual creation - animals - and purely spiritual creation - angels. Stein does not draw the conclusion that a man is neither of those two - she asserts rather that a man is both of them at the same time. He is an animal and an ange ${ }^{31}$. What makes such a connection of the material and the spiritual possible is the form of the soul. As such, the soul is nothing third to body and spirit, though conceptually it remains different from both of them.

\footnotetext{
${ }^{30}$ Ibid., p. 406-408.

31 Ibid., p. 342-343.
} 


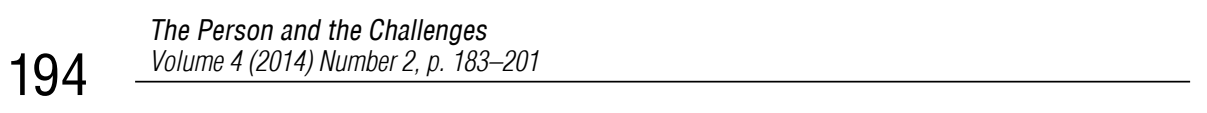

Let us return to the idea of God's presence at the center of a human's soul. Stein's discussion on how sacraments empower a person to reach the final goal of existence includes a side remark about an alternative way of God's activity in a human's soul: from within ${ }^{32}$. The concept of the depth of a soul makes it possible for Stein to admit that Holy Sacraments are not necessary for salvation. Grace, by itself, is, yet it might find its channel of work outside of the external sacraments - that is, through inspirations, motivations or calls of conscience coming from within. Therefore, Stein holds that the center of a soul is in God's hands, more than it is in man's. It remains a domain of God's free activity, even if the external engagement of a person in the world does not aim at receiving grace.

The concept of the center of a soul, a principle of man's unique character, ought to be confronted with a phenomenological term used by Stein in her late anthropology, namely pure ego.

\subsection{Pure ego}

In her early anthropology Stein accepted Husserl's understanding of a pure ego: firstly, as an empty, quality-less, otherwise indescribable subject of experience ${ }^{33}$, secondly, as a unity of a stream of consciousness ${ }^{34}$. In the later period of her thinking she kept using the phenomenological term of a pure ego, offering it a different understanding, however. First of all, she deviated from the idea that the ego has no qualities. Let us regard the following passage: 'Das freie Subjekt - die Person - ist als solches gänzlich ins Leere ausgesetzt. Es hat sich selbst und kann sich selbst nach allen Richtungen bewegen und ist doch mit eben dieser absoluten Freiheit absolut in sich selbst fixiert und zur Bewegungslosigkeit verurteilt. Denn das Selbst, das es hat, ist ein völlig leeres und gewinnt alle Fülle von dem Reich, dem es sich kraft seiner Freiheit hingibt. ${ }^{35}$ Stein implicitly states that the ego might achieve a certain fullness and qualities. In Natur, Freiheit und Gnade, the work

32 E. Stein, Welt und Person, Louvain 1962, Editions Nauwelaerts, p. 184.

${ }^{33}$ E. Stein, On the problem of empathy, trans. W. Stein, Washington 1989, ICS Publications, p. 38. On the same subject in Stein's later philososphy see E. Stein, Endliches und ewiges Sein, Freiburg in Breisgau 1984, Herder, p. 345. p. 38.

${ }^{34}$ E. Stein, On the problem of empathy, trans. W. Stein, Washington 1989, ICS Publications,

${ }^{35}$ E. Stein, Welt und Person, Louvain 1962, Die ontische Struktur der Person und ihre erkenntnistheoretische Problematik, Editions Nauwelaerts, p. 139, 140. 
published with an incorrect title Die ontische Struktur der Person und ihre erkenntnistheoretische Problematik, Stein discussed in detail how the ego might turn to its deepest center and fill its emptiness with inspiration, forces and movements originating from the Kingdom of Grace, thereby reaching a qualitative state.

Secondly, Stein spoke of an ego as a point of attention, a spot in consciousness that can travel through the internal chambers of the soul's castle. She wrote: 'Das Ich erscheint als ein beweglicher Punkt im Raum der Seele; wo es jeweils seinen Standort nimmt, da leuchtet das Licht des Bewußtseins auf und erhellt einen gewissen Umkreis: sowohl im Innern der Seele wie in der gegenständlichen Welt, der das Ich zugewendet ist. Trotz seiner Beweglichkeit ist das Ich aber doch wiederum gebunden: an jenen selbst unbeweglichen Mittelpunkt der Seele, in dem es eigentlich zu Hause ist. Hierhin wird es immer wieder gerufen und zwar - das ist wieder ein Punkt, in dem wir über das hinausgehen mußten, was uns die Seelenburg bezeugt - nicht nur zur höchsten mystischen Begnadung, der geistlichen Vermählung mit Gott, sondern um von hier aus die letzten Entscheidungen zu treffen, zu denen der Mensch als freie Person aufgerufen wird ${ }^{36}$. An ego is the eye of attention which highlights a domain in a person it turns to. It is the decisive power in a man that is responsible for free decisions of conscious life. An ego is also the one that has a body, a soul and a spirit, all open for the ego's exploration. A person, however, is not just an ego. A person is a unity of the structure of body-soul-spirit, in which the ego lives, and is filled with the subconscious and the unconscious. The growth of a body, for instance, is not the ego's activity, yet it is the growth of an ego's body and part of a person's life. This is a step away from Stein's early anthropology in which the pure ego was the subject of all acts and the unconscious ego was placed outside of a phenomenological analysis.

At first glance, the understanding of an ego seems free of theocentric elements. Let us examine it in more detail and confront it with the earlier accepted concept of an ego, since it is one of the terms Stein used in both her phenomenological and post-conversion anthropology.

In her doctoral dissertation Stein analyzed a human being within the context of Husserl's early phenomenology. In the first edition of Logical Investigations

${ }^{36}$ E. Stein, Welt und Person, Louvain 1962, Editions Nauwelaerts, Die Seelenburg, p. 67. See also E. Stein, Endliches und ewiges Sein, Freiburg in Breisgau 1984, Herder, p. 345. 
Husserl rejected Paul Natorp's concept of a pure ego and developed a centerless phenomenological understanding of consciousness. Soon, he came to appreciate Neo-Kantian argumentation for pure ego and already in the second edition of Logical Investigations, as well as in other publications and lectures, he introduced the concept of a pure I. Pure ego eventually became the Archimedean point of his transcendental phenomenology. Stein, who became Husserl's assistant soon after defending her doctoral dissertation, never accepted the idealistic turn of her teacher. In particular, the egocentric orientation of his Cartesian way to the transcendental reduction, was a claim of his philosophy which she never consented to in her own anthropology. In her early philosophy, she did accept an ego as a polar end of all intentions of consciousness - which is one of Husserl's two basic understandings of pure ego - and, therefore, a center of consciousness and the subject of all acts. The unity of a stream of consciousness - argued Stein - is constituted by a pure ego, who is the one and the same polar end of each intention. The role of an ego is therefore essential to a person - were the latter to be deprived of the former, we would not be talking of a person anymore. An ego is a carrier of all conscious acts.

In her later anthropology, Stein rejected the pure ego as a principle of man's unity. An ego remains an element of a person's structure but not the stable, central point of conscious acts. The depth of a soul, also called a center, becomes the fixed, central element. Despite the fact that we have seen little hints of theocentricity in Stein's concept of an ego so far, we have seen, however, an evident step away from the egocentricity of her earlier, phenomenologically inspired thinking ${ }^{37}$. Let us examine if there also is a theocentric tendency in her late work, Endliches und ewiges Sein.

In a commentary to Husserl's concept of an ego Stein discarded egocentricity, at the same time making a shift towards theocentricity ${ }^{38}$. Husserl's conception of a pure ego as the constituent of unity of conscious acts leads to the conclusion that it is an ego who is the carrier and foundation of his own existence. An ego would therefore be a source of his own existence. This - Stein argued - is not coherent with apparent facts concerning the ego's

${ }^{37}$ Stein's anthropological egocentricity was different from Husserl's acceptance of an ego as the Archimedean principle of transcendental phenomenology. The central role of an ego for Stein meant that he is a unifying principle of the stream of consciousness and a central point of consciousness.

${ }^{38}$ E. Stein, Endliches und ewiges Sein, Freiburg in Breisgau 1984, Herder, p. 46-53. 
existence: its ungraspable and mysterious beginning, unpredictable end, gaps in his own past and, most of all, the impossibility to upkeep his own existence. Were an ego a source of his own existence - he would be capable of maintaining it throughout time. Ego, on the contrary, is not in control of his persistence in time: he flows from one moment to another being kept in his existence by something external to him. Ego finds himself thrown into the existence or placed in existence (in Dasein gesetzt) and that, by itself, is contrary to self-sufficiency. Stein cannot but conclude that an ego's existence is offered to him.

'Who is the master of existence then?' we should ask. An answer has already been mentioned above - now it will be derived from the analysis of ego's experience. Once articulated, it will answer the basic question posed in this article about the role of God in Stein's late anthropology.

In his experience, the ego encounters certain limitations: each present moment fades away, memories - once vibrant - fall into oblivion, the foresight of his future contains an inescapable certainty of death. Such limitations are what make an ego reach for the ideals of fullness and perfection, both of which are evidently free from the same limitations which the ego experiences. That is: the analysis of his experience makes an ego encounter the idea of an eternal being. It is this eternal being that must be a source of the ego's finite life - is it therefore concluded that it is God, understood as the one who offers life. Here, once again, the sheer fact of a man's finitude points out to an eternal being. In an earlier paragraph of this article, another aspect of man's finitude was regarded - the incomprehensibility of man without the context of God. God was presented as a theoretical framework in which a finite human being makes sense. Yet another aspect of human's finitude is presented here: the structure of a person is such that an ego encounters domains in himself which are not open to his conscious experience. One perceives them as limitations and searches for an idealization which would be free of them. This idealization is God.

The fact of being offered existence and an experience of limits in his own being are the two aspects of Stein's concept of an ego that include a reference to God. Let us consider the reference to each other. Since God is the one who offers being to ego and since ego is inseparable from his own existence, the offering of life is a precondition of an ego himself. The role of God, for an ego, is indispensible then. To name God's position central is not an overstatement. 


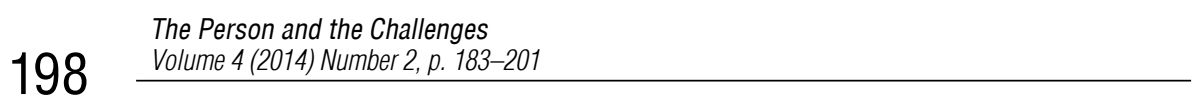

\section{Self-development}

Finally, let us mention the self-development of a person. In her more practice orientated work, Die Frau ${ }^{39}$, Stein considers an individual task each human being ought to realize in his or her life. In order to develop his or her individuality and a true, unique version of humanity one needs: firstly, to understand a particular task given to him or her and, secondly, to muster up enough courage to perform this task. The former - understanding of the task - points to God who is the author of an idea for the best scenario of each person's life. The latter - courage - is, similarly, directed towards God, since it is God's gift. In her understanding of individuality - a term that in contemporary philosophy often is a corner stone for egocentric anthropology - Stein remains faithful to her initial understanding of the proper orientation of philosophy: theocenticity.

\section{Conclusion}

The main thesis proposed in this article states that the role of God in Stein's late anthropological theory is central. Let us recapitulate the crucial points mentioned.

First of all, the finitude of a man as a feature resulting in God being the center of man's existence has been considered. In her treatment of the concept of finitude, Stein explicitly states that finitude simply calls for eternity. The logic of that very term is such that its antonym completes and - consequently - conditions it. One of those terms - finitude - apparently belongs to human experience, since it manifests itself in a number of ways: it is evident in the fact of a man having a temporal existence, marked with a beginning and end, in which certain gaps, interpreted as limitations, occur. As a result, a person is not completely understandable for oneself. All the above mentioned manifestations of the finitude lead up to a short, affirmative statement: finitude is a given. Once this is ascertained, an implication follows: if there is finitude then there must be eternity.

${ }^{39}$ E. Stein, Die Frau, Freiburg 2010, Herder. English translation: Essays on Woman, trans. F. M. Oben, Washington 1996, ICS Publications. 
Eternity is the only framework in which the existent finitude finds its explanation: God is the creator of man and his origin; He also is the aim of each person's life, thereby offering sense to the dynamic, evolving and incomplete being of man; God is a beholder of man's life in status viae, sustaining his temporal, fragile existence and an endless source of inspiration to live it.

Secondly, Stein accepts an iconic structure of a human being: all men are icons of one triune God. The mark of this iconicity shapes the basic structure of a person into a threefold combination of a living body (Leib), spirit and a soul. The blending of those three is achieved by the form of a soul. It is not just the general structure that is dependent on God in Stein's anthropology: each element of man's structure is related to the eternal being in a fundamental way.

In her understanding of a body Stein accepts the hylomorphic relation of a soul and a living body. In her view, the body plays the role of the instrument for a spirit manifesting itself in personal acts and creations. This does not lead Stein to a Platonic kind of anti-somatic standpoint which would underplay man's physicality. On the contrary, the body is dignified by the fact that it is a tool for spiritual substance. The body is a mirror reflecting the life of a soul and as such, it takes over the orientation towards God that is characteristic for the soul.

The description of a soul justifies accepting the literal meaning of theocentricity in Stein's anthropology: a metaphor of the soul as a castle - adopted from St. Teresa of Avila's The interior castle or the mansions - leads Stein to considerations of a most internal, central part of the soul, sometimes called the depth of a soul. The center is a domain where a human being encounters life that is not his own: at the depth of the soul a person might receive inspiration and movement coming from above. This is because the center is a channel of God's grace, specifically placed in man in order to lead him towards his final goal. When external dealings with the world do not overshadow that deep central point, a person might reach the silent source. Then, it becomes a shelter in which one gains strength offered by God. Stein's understanding of the center of a soul includes the fact that the center is a domain of God's activity in a human being and, moreover, a sphere where God can be actually present. The latter expression is a most literal articulation of the theocentricity of Stein's anthropology.

The person's body-soul-spirit unity is a domain of the ego's free exploration. In her post-conversion treatment of the ego, Stein discarded all egocentricity: 
an ego was no more a principle of unity of a stream of consciousness. It became a moving, conscious eye which can lead the way into the depth of a soul. The role of a foundation of existence is played by the eternal being. Pure ego is merely an element in an iconic structure of a person.

The above listed elements of Stein's anthropological reflection are reason enough to call her post-conversion reflection on man a theocentric one. The structure of a person in Stein's late work becomes fully comprehensible only when placed within the ontological framework of God. Strictly speaking, the distinction between an ontological reflection on a human being and an ontological reflection on God is not at all sharp: a theocentric anthropology ceases to be merely anthropology - it rather is a sub-domain of a philosophy of God.

\section{Bibliography}

Adamska I. J., Święta Edyta Stein, Kraków 2003, Wydawnictwo Karmelitów Bosych.

Baseheart M. C., Person in the World: Introduction to the Philosophy of Edith Stein, Dordrecht 1997, Kluwer.

Grzegorczyk A.: Edyta Stein - filozofia Światta, in: (ed.) Z. Kuderowicz, Filozofia XX wieku, Warszawa 2002, Wiedza Powszechna.

Machnacz J., Wierność (O)sobie. Szkic do antropologii Edyty Stein, Itinera Spirytualia 4 (2011), p. 71-92.

McIntyre A., Edith Stein. A Philosophical Prologue 1913-1922, Maryland 2006, Rowman \& Littlefield Publihers.

Sancho Fermin F. J., Edyta Stein. Część 3: Nauka, Poznań 2012, Flos Carmeli.

St. Augustine, On the Trinity, trans. A. W. Haddan, - http://www.logoslibrary.org/augustine/ trinity/index.html (20.05.2014).

Stein E., Der Aufbau der menschlichen Person. Vorlesung zum Philosophischen Anthropologie, Freiburg-Basel-Wien 1994, Freiburg 2010, Herder.

Stein E., Die Frau, Freiburg 2010, Herder. English translation: Essays on Woman, trans. F. M. Oben, Washington, 1996, ICS Publications.

Stein E., Endliches und ewiges Sein, Freiburg in Breisgau 1984, Herder, the new edition: Freiburg 2013, Herder. English translation: Finite and eternal being, trans. K. F. Reinhardt, Washington 2002, ICS Publications.

Stein E., Erkenntnis und Glaube, Freiburg 1993, Herder, chapter Was Ist Philosophie? Ein Gespräch zwischen Edmund Husserl und Thomas von Aquino.

Stein E., Geistliche Texte I, Freiburg 2014, Herder.

Stein E., Geistliche Texte II, Freiburg 2007, Herder.

Stein E., Husserls Phänomenologie und die Philosophie des hl. Thomas von Aquino: Versuch einer Gegenüberstellung, in: Jahrbuch für Philosophie und phänomenologische 
Forschung, Festschrift fur Edmund Husserl, zum 70. Geburstag gewidmet, Halle 1929, p. 315-338. English translation: Person in the World: Introduction to the Philosophy of Edith Stein, trans. M. C. Baseheart, Dordrecht 1997, Kluwer, p. 129-144 and 179-180.

Stein E., Was is der Mensch? Theologische Anthropologie, Freiburg 2005, Herder.

Stein E., Welt und Person, Louvain 1962, Editions Nauwelaerts.

Stein E., Zum Problem der Einfühlung, Freiburg 2010, Herder. English translation: On the problem of empathy, trans. W. Stein, Washington 1989, ICS Publications. 